\title{
Analysis of Geochemical Characteristics Prospecting Prospects of Nickel Polymetallic Ore in Langmuri Dulan County of Qinghai
}

\author{
Liu Zhihua, Chen Jianlin, Zhang Dexiang, Li Yulu
}

Qinghai First Institute of Geological Exploration, 810600, China

Keywords: Dulan, Qinghai, Langmuri nickel polymetal, Geochemical characteristics, Prospecting prospects

\begin{abstract}
The Langmuri Nickel Polymetallic Ore is located in the eastern part of the East Kunlun metallogenic belt (East Kunlun Central Orogenic Belt) in Qinghai Province, lying in the Berkalik-Xiangride Indosinian polymetallic metallogenic belt. The stratum of Baishahe Formation is widely exposed in the area, and the structural characteristics of the area are very prominent, showing obvious multi-phase characteristics, which seriously affects the production and distribution direction of the strata in the area. There are obvious magmatic rocks in the area, including not only basic magmatic rocks but also ultrabasic magmatic rocks. For example, syenogranite and monzonitic granite are widely developed in this area, and they are the main occurrence of the main ore bodies in this area. These nickel mineralization clues indicate that the eastern section of East Kunlun also has the potential to find nickel polymetallic deposits.
\end{abstract}

\section{Introduction}

Due to the distribution pattern of sedimentary construction and magmatic activity in the East Kunlun metallogenic belt, the geotectonic structure of this area is clamped between the Qimantage-Dulan suture zone and the East Kunlun middle suture zone. The geological structure is complex in the area: tectonic faults are distributed in the northwest-northwest direction; magmatic rocks occupy most of the space with the Variscan-Indosinian intermediate-acid intrusive rocks, forming the Kunlun Northern magmatic arc zone; the strata are composed of the Late Archaean-Paleoproterozoic Baishahe Rock Formation and the Middle and Late Proterozoic Xiaomiao Formation ${ }^{[1,2]}$. Two ultra-basic rock bodies, namely $\Sigma 1$ and $\Sigma 2$, have been found in the area, and one nickel polymetallic ore body (M1) is circled in the $\Sigma 1$ ultra-basic rock body, which has great prospecting potential.

\section{Regional Geological Features}

\subsection{Stratum}

The regional outcropping strata include the Early Proterozoic Baishahe Formation (Pt1b), which is mainly outcropped in the central and southern regions. It is generally distributed in a northwest-west-near-east-west direction. This is a set of advanced metamorphic rock series, which constitutes the crystalline base of the Qaidam ancient land. Due to the influence of multiple magmatic activities in the later, only a small amount of this formation remains, which is widely exposed in the northern part of the mapsheet. The Early Carboniferous Halaguole Formation (C1hl) is mainly distributed in the southwestern part of the regional mapsheet. It is a set of sedimentary formations with greywacke and slate interbedding. Its sedimentary thickness is greater than $650 \mathrm{~m}$, and it is in parallel and integrated contact with the Upper Carboniferous strata. The Elashan Formation (T3e) is distributed in a small amount in the north-eastern corner of the mapsheet and is composed of acidic or intermediate-acid volcanic rocks. The lower part of it contains clastic rocks and coal lines, and some areas are dominated by clastic rocks. Volcanic rocks gradually transition from neutral to acidic and from bottom to top. The Nagengkangche large silver bed produced in the north east corner of the pre-investigation area is present in this set of strata; and the Quaternary (Q) 
was is also found in this area.

\subsection{Construction}

This area is located on the north side of the central Kunlun fault zone and belongs to the ocean-continent subduction zone (Early Paleozoic). Thrust nappe faults are widely developed in the area and have very prominent structural mixing characteristics. Prominent fault structures developed in this area, mainly compressive or compressive torsion fracture, and they constitute the backbone structure.

\subsection{Magmatic Rocks}

This area belongs to the East Kunlun magma arc belt, which is the east edge of the magma arc (multi-cycle). The formation and development of the Kunnan Ocean and the ancient Kunzhong Ocean are very closely related to the granite (multiple periods and types) in the region. Intrusive rocks are very well developed in this area, mainly in the variscan and Indosinian periods. At the same time, the granodiorite formed in the late Caledonian period is less developed in this region ${ }^{[3]}$.

Some ultrabasic rocks are distributed in the pre-surveyed area. The output mainly presents a belt-like characteristic, and the distribution characteristic is the same as that of the fault structure. Peridotite is its main lithological feature. The variscan intermediate-acid rock masses are widely developed in this area, and the Caledonian, Indosinian and Yanshanian intermediate-acid intrusions are also distributed.

\section{Geochemical Characteristics}

Since 2014, a 1:25,000 river sediment survey has been carried out in the census area, and a total of 10 comprehensive anomalies dominated by $\mathrm{Cu}, \mathrm{Ni}$, and $\mathrm{Co}$ have been circled, of which 7 are $\mathrm{Co}$ anomalies and 3 are $\mathrm{Ni}$ anomalies, of which the larger ones are the $\mathrm{HS}^{70}{ }_{\mathrm{Ni} 2}$ abnormality, $\mathrm{HS}^{71}{ }_{\mathrm{Ni} 3}$, $\mathrm{HS}^{73}{ }_{\mathrm{Ni} 2}$ abnormalities and $\mathrm{HS}^{75}$ Co abnormality.

\section{$3.1 \mathrm{Hs}^{70}{ }_{\text {ni2 }}$ Abnormality}

The anomaly area is located in the northern part of the pre-surveyed area and is a comprehensive multi-metal anomaly mainly composed of $\mathrm{Ni}, \mathrm{Cu}$ and $\mathrm{Co}$. It is composed of elements such as $\mathrm{Ni}, \mathrm{Cu}$, $\mathrm{Co}, \mathrm{Au}$, etc., with good fit. The anomaly is generally in a long strip of northwest direction, with a length of about $1.5 \mathrm{~km}$, a width of about $500 \mathrm{~m}$, and an area of about $0.7 \mathrm{~km}^{2}$. The concentrated center is obvious. The anomaly scale of $\mathrm{Ni}$ is relatively large, and that of other elements is relatively small. In this anomaly area, the $\mathrm{Ni}$ anomaly spreads in a long strip in the northwest direction, and the peak value of Ni58 is $1462.2 \times 10^{-6}$, with an inner zone concentration center. The $\mathrm{Cu}$ anomaly is distributed in a long strip in the northwest direction, and the peak value of Cu77 is $538.1 \times 10^{-6}$, with an inner zone concentration center. Co anomalies are scattered along the northwest direction in short strips, and the peak value of Co69 is $148 \times 10^{-6}$, with an inner zone concentration center. The $\mathrm{Au}$ anomaly is distributed in a short strip in the northwest direction, and the peak value of Au88 is $9.37 \times 10^{-9}$, with a middle zone concentration center. The outliers of other elements are low and the anomaly scale is small. The anomaly parameters and characteristics are shown in Table 1.

The gray biotite plagioclase gneiss, mixed rock, granulite and mixed gneiss of the Baishahe Formation are the main exposed rock types in the area. Granite and diorite dikes are developed in the stratum, and ultrabasic rock masses can be seen locally.

The structure is relatively developed in the anomaly area, which is mainly manifested as a north-east-trending fault. In this abnormal fault, the parameters of $\mathrm{Ni}, \mathrm{Cu}, \mathrm{Co}$ and $\mathrm{Au}$ show good geochemical mineralization characteristics. The anomaly peak is relatively high, and all element fit well. It is inferred that there are ultrabasic dykes and tectonic alteration zones in the anomaly area, which have directivity for finding $\mathrm{Ni}, \mathrm{Cu}, \mathrm{Co}, \mathrm{Au}$ and other deposits in this area. 
Table 1 Characteristics of Various Element Parameters of $\mathrm{Hs}^{70}{ }_{\mathrm{Ni} 2}$ Comprehensive Anomaly

\begin{tabular}{|l|l|l|l|l|l|l|l|l|l|l|}
\hline No. & Points & $\begin{array}{l}\text { Anomaly } \\
\text { threshold }\end{array}$ & $\begin{array}{l}\text { Mean-squar } \\
\text { deviation }\end{array}$ & $\begin{array}{l}\text { Peak } \\
\left(10^{-6}\right)\end{array}$ & $\begin{array}{l}\text { Contrast } \\
\text { value }\end{array}$ & $\begin{array}{l}\text { Mean } \\
\left(10^{-6}\right)\end{array}$ & $\begin{array}{l}\text { Area } \\
\left(\mathrm{Km}^{2}\right)\end{array}$ & $\begin{array}{l}\text { Coefficient } \\
\text { of variation } \\
(\mathrm{Cr})\end{array}$ & $\begin{array}{l}\text { Anomaly } \\
\text { scale }\end{array}$ & $\begin{array}{l}\text { Concentration } \\
\text { zoning }\end{array}$ \\
\hline Ni58 & 10 & 50 & 493.17 & 1462.2 & 6.30 & 314.92 & 0.49 & 1.57 & 3.09 & $\begin{array}{l}\text { Inner, } \\
\text { middle and } \\
\text { outer }\end{array}$ \\
\hline Au88 & 2 & 3 & 0.90 & 9.37 & 2.91 & 8.74 & 0.06 & 0.10 & 0.17 & $\begin{array}{l}\text { Middle and } \\
\text { outer zones }\end{array}$ \\
\hline Cu77 & 5 & 50 & 207.37 & 538.1 & 3.84 & 191.90 & 0.22 & 1.08 & 0.84 & $\begin{array}{l}\text { Inner, } \\
\text { middle and } \\
\text { outer }\end{array}$ \\
\hline Co68 & 2 & 20 & 2.19 & 23.4 & 1.09 & 21.85 & 0.06 & 0.10 & 0.07 & Outer zone \\
\hline Co69 & 2 & 20 & 17.54 & 148 & 6.78 & 135.60 & 0.08 & 0.13 & 0.54 & $\begin{array}{l}\text { Inner, } \\
\text { middle and } \\
\text { outer }\end{array}$ \\
\hline Bi40 & 1 & 1 & $/$ & & & & & & & \\
\hline
\end{tabular}

Note: The unit of $\mathrm{Au}$ and $\mathrm{Ag}$ is $10^{-9}$; the unit of other elements is $10^{-6}$.

\section{2 $\mathrm{Hs}^{71}{ }_{\text {ni3 }}$ Abnormality}

This anomaly area is located in the west part of the pre-surveyed area and is a comprehensive multi-metal anomaly mainly composed of $\mathrm{Ni}, \mathrm{Cu}$ and $\mathrm{Co}$. It is composed of elements such as $\mathrm{Ni}, \mathrm{Cu}$, $\mathrm{Co}, \mathrm{Au}$, etc., with good fit. The anomaly is generally in a long strip northwest direction, with an area of about $0.51 \mathrm{~km}^{2}$ and an obvious concentration center. The scale of $\mathrm{Ni}$ anomaly is large, and the scale of other element anomalies is small. Among them, the Ni anomaly spreads in a long northwest direction. The anomaly peak of Ni59 is $495.2 \times 10^{-6}$, with a concentrated center of inner zone. The Co element anomaly spreads northwest in a strip shape. The anomaly peak value of Co105 is $81.5 \times 10^{-6}$. The anomaly parameters and characteristics are shown in Table 2, and Figure 1 shows the anomaly analysis.

Table 2 Characteristics of Various Element Parameters of $\mathrm{Hs}^{71}{ }_{\mathrm{Ni} 3}$ Comprehensive Anomaly

\begin{tabular}{|l|l|l|l|l|l|l|l|l|l|l|}
\hline No. & Points & $\begin{array}{l}\text { Anomaly } \\
\text { threshold }\end{array}$ & $\begin{array}{l}\text { Mean-square } \\
\text { deviation } \\
\left(10^{-6}\right)\end{array}$ & $\begin{array}{l}\text { Contras } \\
\text { value }\end{array}$ & $\begin{array}{l}\text { Mean } \\
\left(10^{-6}\right)\end{array}$ & $\begin{array}{l}\text { Area } \\
\left(\mathrm{Km}^{2}\right)\end{array}$ & $\begin{array}{l}\text { Coefficient } \\
\text { of variation } \\
(\mathrm{Cr})\end{array}$ & $\begin{array}{l}\text { Anomaly } \\
\text { scale }\end{array}$ & $\begin{array}{l}\text { Concentration } \\
\text { zoning }\end{array}$ \\
\hline Ni59 & 8 & 50 & 170.62 & 495.2 & 4.04 & 201.93 & 0.32 & 0.84 & 1.30 & $\begin{array}{l}\text { Inner, middle } \\
\text { and outer }\end{array}$ \\
\hline Cu96 & 2 & 50 & 7.00 & 95.4 & 1.81 & 90.45 & 0.10 & 0.08 & 0.18 & Outer zone \\
\hline Co70 & 2 & 20 & 2.19 & 24.1 & 1.13 & 22.55 & 0.02 & 0.10 & 0.02 & Outer zone \\
\hline Co105 & 3 & 20 & 29.96 & 81.5 & 2.90 & 57.90 & 0.13 & 0.52 & 0.38 & $\begin{array}{l}\text { Inner, middle } \\
\text { and outer }\end{array}$ \\
\hline Au96 & 1 & 3 & $/$ & 3.33 & 1.11 & 3.33 & 0.02 & $/$ & 0.02 & Outer zone \\
\hline
\end{tabular}

Note: The unit of Au and Ag is $10^{-9}$; the unit of other elements is $10^{-6}$.

The gray biotite plagioclase gneiss, mixed rock, granulite and mixed gneiss of the Baishahe Formation are the main exposed rock types in the area. According to the anomaly interpretation of geophysical and magnetic method, there is a certain scale of ultrabasic rock intrusion.

The ultrabasic rock mass delineated in this anomaly area is believed to be the same one as the ultrabasic rock mass found in the east side of the $\mathrm{HS}^{73}$ abnormality. In the later period, the rock mass morphology was displaced due to the influence of the north-east trending fault structure. In this anomaly area, the parameters of $\mathrm{Ni}$ and $\mathrm{Co}$ elements show good geochemical mineralization characteristics. The anomaly peak value is relatively high, and the compatibility of each element is good, indicating that it is a good target area for prospecting $\mathrm{Ni}$ and Co minerals. 


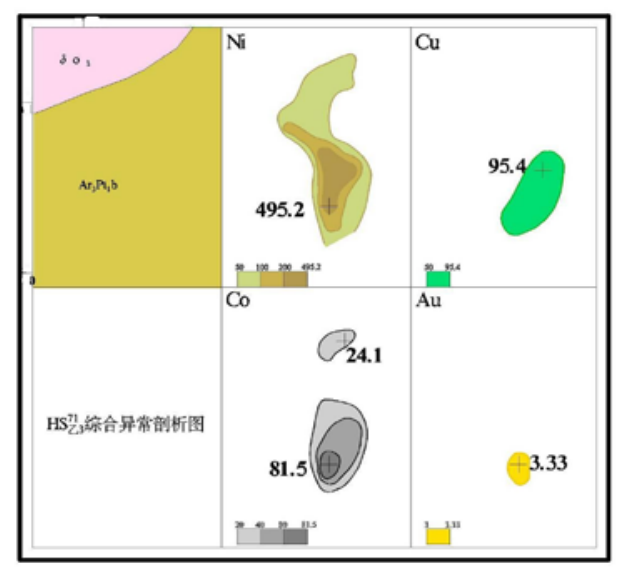

Fig. $1 \mathrm{Hs}^{71}{ }_{\text {ni3 }}$ Comprehensive Anomaly Analysis

\section{$3.3 \mathrm{Hs}^{75}$ co $\square$ Abnormality}

This anomaly is located in the south part of the pre-surveyed area and is a comprehensive abnormality dominated by $\mathrm{Co}$ and Ni. The anomaly is generally elongated and distributed in a nearly east-west direction, with an area of about $0.56 \mathrm{~km}^{2}$ and an obvious concentration center. The $\mathrm{Ni}$ anomaly is large in scale and spread in the north-east direction. The anomaly peak of Ni93 is $481.7 \times 10^{-6}$, with an inner zone concentration center, and an anomaly area of $0.14 \mathrm{~km}^{2}$. The anomaly peak of Ni110 is $65.9 \times 10^{-6}$, with a concentrated center of inner zone. The anomaly parameters and characteristics are shown in Table 3.

Table 3 Characteristics of Various Element Parameters of $\mathrm{Hs}^{75}$ co Comprehensive Anomaly

\begin{tabular}{|l|l|l|l|l|l|l|l|l|l|l|}
\hline No. & Points & $\begin{array}{l}\text { Anomaly } \\
\text { threshold }\end{array}$ & $\begin{array}{l}\text { Mean-square } \\
\text { deviation }\end{array}$ & $\begin{array}{l}\text { Peak } \\
\left(10^{-6}\right)\end{array}$ & $\begin{array}{l}\text { Contras } \\
\text { value }\end{array}$ & $\begin{array}{l}\text { Mean } \\
\left(10^{-6}\right)\end{array}$ & $\begin{array}{l}\text { Area } \\
\left(\mathrm{Km}^{2}\right)\end{array}$ & $\begin{array}{l}\text { Coefficient } \\
\text { of variation } \\
(\mathrm{Cr})\end{array}$ & $\begin{array}{l}\text { Anomaly } \\
\text { scale }\end{array}$ & $\begin{array}{l}\text { Concentration } \\
\text { zoning }\end{array}$ \\
\hline Co110 & 4 & 20 & 20.06 & 65.9 & 1.96 & 39.23 & 0.19 & 0.51 & 0.37 & $\begin{array}{l}\text { Middle } \\
\text { outer zones }\end{array}$ \\
\hline Ni93 & 6 & 50 & 172.69 & 481.7 & 3.19 & 159.33 & 0.14 & 1.08 & 0.46 & $\begin{array}{l}\text { Inner, middle } \\
\text { and outer }\end{array}$ \\
\hline Ag162 & 3 & 140 & 30.45 & 206 & 1.28 & 179.00 & 0.05 & 0.17 & 0.06 & Outer zone \\
\hline
\end{tabular}

Note: The unit of Au and Ag is $10^{-9}$; the unit of other elements is $10^{-6}$.

The exposed rocks in the anomaly area are mainly the biotite plagioclase gneiss of the Baishahe Formation. The interpretation with the 1:10,000 magnetic profile shows that there are obvious positive and negative anomalies in the east part of the anomaly, which means that there may be underlying ultrabasic rock masses. In this anomaly area, the parameters of $\mathrm{Ni}$ and Co elements show good geochemical mineralization characteristics. The anomaly peak is high, but the elements fit well and the anomaly scale is small. This anomaly is Co abnormality, which has certain indicative significance for $\mathrm{Ni}$ and $\mathrm{Co}$ ore prospecting.

\section{Characteristics of Mineralized Bodies}

Basic-ultrabasic rock mass is a preliminary indicator for finding $\mathrm{Cu}-\mathrm{Ni}$ ore, so it is particularly important to understand the spatial distribution and mineralization of rock masses. There are two ultrabasic rock bodies ( $\Sigma 1$ and $\Sigma 2$ ) of varying sizes in the $\mathrm{HS}^{73 \square}$ abnormality in this area.

The search for $\mathrm{Cu}-\mathrm{Ni}$ ore in this area is very closely related to basic and ultrabasic rock masses. Therefore, it is very important to fully understand the distribution characteristics and their mineralization of rock masses ${ }^{[4,5]}$. There are two ultrabasic rock bodies of different sizes in the $\mathrm{HS}^{73}$ abnormality.

\section{1 $\Sigma 1$ Ultrabasic Rock Mass}

The distribution of the rock mass is mainly north-west, with a length of about 30-100m exposed on the surface area. The anomaly is delineated by the 1:10,000 magnetic method, and the deep part 
is about $3 \mathrm{Km}$ long and 400-600m wide. A 36-84m-wide polymetallic anomaly zone is encircled in the ultrabasic rock body, initially controlled by three geochemical profiles. The anomalous area of the profile was exposed by trenching methods, and a NiCuCO ore body was found in this area, labeled M1. Altered peridotite is the main lithological feature of the ore body. Malachite and limonite alteration features are prominent, and pentlandite is widely developed. From these, it can be inferred that nickel sulfide is the main mineralization type of the ore.

M1 ore body: it is controlled by $\Sigma 1 \mathrm{TC} 01$ exploratory trench and 16YP1 and 16YP2 profiles; the length is about $500 \mathrm{~m}$ and the width is $3-7.5 \mathrm{~m}$. The $\mathrm{Cu}-\mathrm{Ni}$ mineralized zone in this area is about 20 meters wide, where the ore bodies are distributed. The grade characteristics of $\mathrm{Ni}$ in this zone reach $0.13-0.17 \%$, and the average grades of $\mathrm{Ni}$ and $\mathrm{Cu}$ in the $\mathrm{M} 1$ ore body are $0.29 \%$ and $0.30 \%$ respectively. Cu-Ni rich ore bodies have a width of about 3 meters distributed on the hanging wall, and the average grades of $\mathrm{Cu}$ and $\mathrm{Ni}$ reach $0.40 \%$ and $0.36 \%$ respectively. In accordance with the characteristic that a large number of ore bodies are produced in the $\mathrm{Cu}-\mathrm{Ni}$ mineralized zone, it is believed that the ore bodies show the characteristics of continuous expansion in the deep position.

Controlled by the profile to the west, there is an ore body about $3 \mathrm{~m}$ wide. According to the analysis of block samples in this area, the grade of $\mathrm{Ni}$ is $0.32-0.54 \%$, the grade of $\mathrm{Cu}$ is $0.3-0.55 \%$, and the grade of Co is $0.017-0.044 \%$. The westward ore body presents the characteristic of stable output and at the same time it has superior mineral-bearing properties. Engineering control is relatively low in this area.
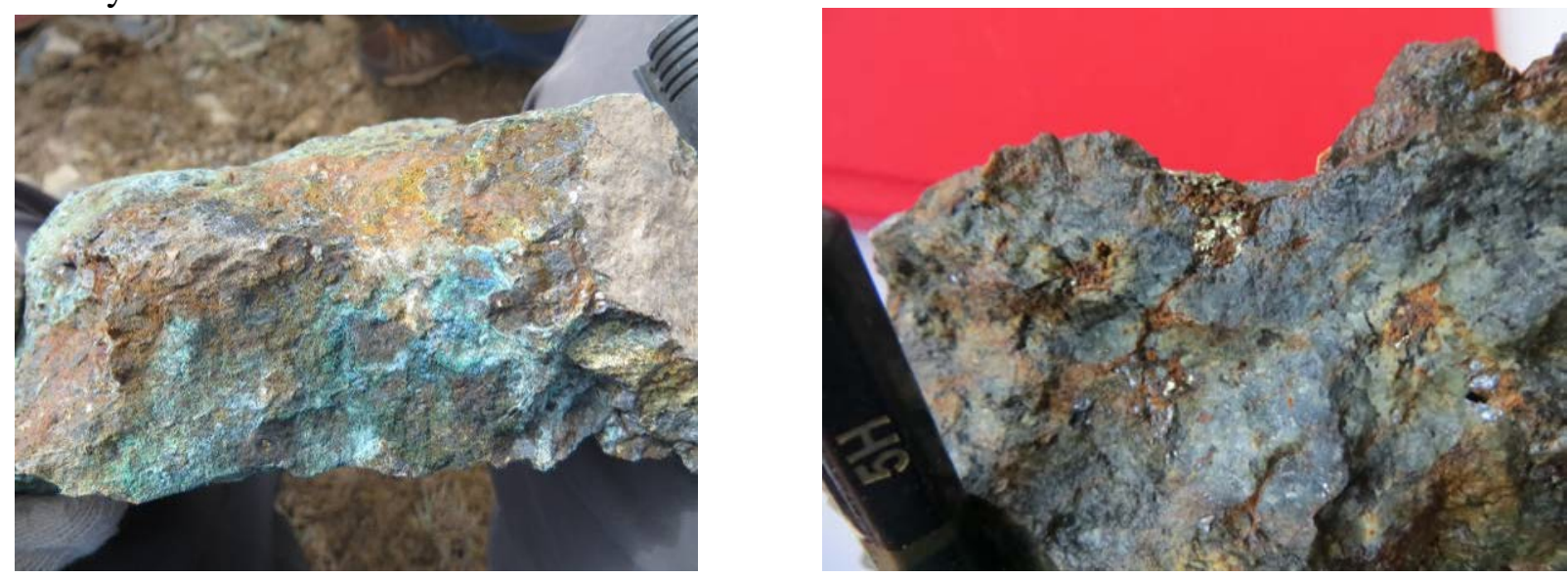

Figure 2 Ore photos of $\Sigma 1$ ultrabasic rock mass

\section{$4.2 \Sigma 2$ Ultrabasic Rock Mass}

$\Sigma 2$ ultrabasic rock mass is distributed in the westward direction of $\mathrm{HS}^{73}$ comprehensive anomaly, and the distribution is nearly east-west. The 20-30m width is controlled currently, and the length is about $150 \mathrm{~m}$. Peridotite is its main ultrabasic rock. The ferritization is very prominent on the rocks, and the pentlandite is star-shaped. It is found through sample collection and analysis that the grade of $\mathrm{Ni}$ is $0.39 \%$ and the grade of $\mathrm{Co}$ is $0.018 \%$.

\section{Prospecting Prospects}

There are 10 1:25,000 comprehensive geochemical anomalies in the area that have been circled in the area. They have very good element fit and obvious characteristics of element combination. These areas present very superior geological conditions. Migmatite and the Baishahe Formation (Jinshuikou Group) which is composed of biotite plagioclase gneiss (grey) and mixed gneiss and granulite are the main lithological features of this area. There is a large amount of pentlandite distributed in this ultrabasic rock body, and the prominent ones include chalcopyrite, pyrite, ilmenite and pyrrhotite

Due to the insufficient deep research work in these areas, the basic information of the current ore body is not completely clear. The drilling site is on the near surface area of the rock mass. Combined with the current superior geological conditions, nickel polymetallic ore can be found in 
its shallow and deep positions and has a certain scale. Therefore, the area has good prospecting potential.

\section{Conclusion}

The ore is located in favorable conditions in terms of regional stratum, structure and magmatic rock, which provides an extremely favorable foundation for mineralization in the region. This is extremely beneficial to the search for nickel polymetallic deposits. The existing analysis showed that the superior mineralization conditions are extremely favorable for the search for nickel ore in the area. The intersection of the faults in the area is distributed with very prominent ultra-basic rock masses. The geological characteristics and the types of mineralization and alterations in the area show that the shallow and deep areas have great mineralization potential. Therefore, it is needed to strengthen the research work in this area to seek a greater breakthrough in prospecting.

\section{References}

[1] Wu Shukuan, Zhang Yuan, Yang Qi'an, etc. Geological characteristics and prospecting potential of the II intrusion of Xiahamu Cu-Ni deposit in East Kunlun orogenic [J]. Non-ferrous Metals (mining part), 2017, 69(1): 34-35.

[2] Li Shijin, Sun Fengyue, Gao Yongwang, etc. The Theoretical Guidance and Practice of Small Intrusions Forming Large Deposits -- The Enlightenment and Significance for Searching breakthroughs of Cu-Ni Sulfide Deposit in Xiahamu, East Kunlun, Qinghai [J]. Northwest Geology, 2012,45(4):185-186.

[3] Wang Guan, Sun Fengyue, Li Bile, etc. Zircon U-Pb Chronology, Geochemistry and Dynamic Significance of Early Devonian Syengranite in Xiahamu Mining Area, East Kunlun[J. Geotectonica et metallogenia, 2014, 37(4):685-697.

[4] Zhang Jinling, Li Linggui, Yang Qi'an and Li Min. Geological and Geochemical Characteristics and Significance of Xiahamu Cu-Ni Deposit Based on Borehole Information [J]. Science Technology and Engineering, 2016, 16(18): 125-126.

[5] Kong Deyan, Hu Ying. Geological characteristics and ore-controlling factors of Xiarihamu copper polymetallic deposit [J]. Journal of Qinghai University (Natural Science Edition), 2014, 32(6): 64-65. 